\title{
PREFERENSI NASABAH NON-MUSLIM TERHADAP BANK SYARIAH (Studi pada Bank Syariah Mandiri Cabang Palangka Raya)
}

\author{
Surya Sukti, Muhammad Aliansyah
}

\begin{abstract}
Bank Syariah Mandiri 'Palangka Raya branch in 2010 was up to the point: the most customers were non-loading religious customers, $70 \%$ of which were non-Muslim clients and 30\% were Muslim customers. The question is, why are there more non-commissioned communities who prefer to transact in Bank Syariah Mandm 'Palangka Raya and "to Muslims. Peneh'ti is interested in conducting studies that focus on the preferences of non-customer customers of Mandiri Bank Syariah Branch Palangka Raya The purpose of this study is to describe the frequency of the study, the study uses a qualitative method approach.The results of this study show that preferential non-mushroom customers to the Bank Syariah Mandm branch of Palangka Raya are customary because the service of bank employees is good and friendly, facility expressions, not many queues like old banks, and benefits that customers get.The nonformal customer response to the Bank Syanah Mandiri branch of the Palangka Raya branch is common because it is almost the same as other bank products. and mustim tend to run in the Bank Syanah Mandiri, Palangka Raya branch, yam; ek factor internal and internal factors. The encouragement or motivation of customers to transact at Bank Syariah Mandm 'Palangka Raya Branch is not due to religious motivation or consideration (halat / haram). This reality reinforces the view that religious factors (abortion / haram) are not the main consideration in the selection of Islamic banks. This does not mean to consider religious considerations or Islamic issues in them. But the safat of rationality influences the natural freedom of customers in choosing banks to transact and get the expected benefits.
\end{abstract}

Keywords: Sharia Bank, Customer, Non Muslim

ABSTRAK

Bank Syariah Mandiri' cabang Palangka Raya pada 2010 hingga ...ang, penentu: yang menjadi nasabah terbanyak adalah nasabah yang beragama non-muatun yakni $70 \%$ nasabah nonmuslim dan 30\% nasabah muslim. Yang menjadi pertanyaannya adalah, mengapa lebih banyak masyarakat non-muslim yang cenderung memilih bertransaksi di Bank Syariah Mandm' Palangka Raya dan" pada yang muslim. Penelitian ini tertarik melakukan kajian yang berfokus pada preferensi nasabah non-rnush'm terhadap Bank Syariah Mandiri Cabang Palangka Raya. Tujuan studi ini untuk mendeskripsikan jawaban dari bagaimana hal tersebut. Studi im menggunakan pendekatan dcsknptif kualitatif. Hasit studi ini menunjukan bahwa prefermsn nasabah non-mushnl terhadap Bank Syariah Mandm cabang Palangka Raya adatah karena petayanan karyawan bank itu sendm' yang baik dan ramah, kelmgkapan fasilitas, antrian yang tidak banyak seperti bank lam, dan keuntungan yang dldapatkan nasabah. Tanggapan nasabah non-muslml trrhadap pmduk Bank Syanah Mandiri cabang Palangka Raya adalah biasa-bmsa sap karena hampir sama dengan produk bank lain. Faktor yang mendorong nasabah r.an-mustim cenderung mum! bertransalm' di Bank Syanah Mandiri cabang Palangka Raya, yam; faktor eksternal dan faktor internal. Dorongan atau motivasi nasabah bertransaksi di Bank Syariah Mandm' Cabang Palangka Raya tidak karena motivasi atau pertimbangan agama (halat/haram). Realitas ini memperkuat pandangan yang mengatakan bahwa faktor agama (hatal/haram) 
bukanlah pertimbangan utama dalam pemilihan bank syariah. Hal ini tidak bermaksud mengenyampmgkan pertimbangan agama atau pn'nsip-pn'nsip syariah yang ada di dalamnya. Namun safat rasionalitas yang lebuh memptngaruhi kebebasan alamiah para nasabah dalam memilih bank untuk bertransaksi dan mendapatkan keuntungan yang diharapkan. Kata Kumci: bank syariah, nasabah, non muslim

\section{A. Pendahuluan}

Hadirnya Bank Syariah di Indonesia hingga saat ini telah direspon positif oleh Bank Indonesia dalam perkembangannya. Hal ini ditandai dengan dibukanya Biro Perbankan Syariah di Indonesia. Volume usaha perbankan syariah akan terus meningkat, didukung perluasan jaringan kantor dan produk bank syariah yang makin lengkap pula seperti halnya bank umum lainnya. Bank-bank konvensional ramai-ramai membuka unit syariah, bahkan ada bank yang semula beroperasi secara konvensional, kini hijrah menuju bank umum yang sepenuhnya menerapkan konsep syariah. Sehingga hal ini menandai telah diberlakukannya sistem perbankan ganda (Dual Banking System) dalam sistem perbankan di Indonesia. Upaya pengembangan Bank Syariah tidak cukup hanya berlandaskan kepada aspek-aspek legal dan peraturan perundangundangan, tetapi juga harus berorientasi kepada pasar atau masyarakat sebagai pengguna jasa.

Pesatnya perkembangan perbankan syariah juga telah diikuti dengan pesatnya kajian dan publikasi mengenai prunsip-prinsip serta praktek-praktek bank nyariah. Namun demikian. berbagai kajian dan terbitan tersebut hampir seluruhnya membahas bagaimana strategi sukses mengelola bank syariah dengan memfokuskan pada nasabah muslim sebagai sasaran utamanya. Tetapi yang jadi pertanyaanya adalah; apakah bank syariah tidak sesuai untuk nasabah nonmuslim?.

Dalam konteks Indonesia, hal ini sangat penting untuk dipikirkan, mengingat bahwa non muslim di Indonesia selain jumlahnya cukup signifikan, juga memiliki potensi ekonomi yang besar. Hal ini diperkuat dengan kenyataan pada beberapa wilayah di Indonesia, bahwa penduduk non muslimlah yang merupakan mayoritas. ${ }^{1}$

Dalam upaya perkembangannya bank syariah tidak hanya memproyeksikan sasaran nasabahnya pada masyarakat yang muslim saja, tetapi tidak menutup kemungkinan juga pada masyarakat non-muslim. Sebab, agama Islam tidak membedakan antara orang muslim dan nonmuslim. Sebab, agama Islam tidak membedakan antara orang muslim dan non-muslim dalam bidang muamalah, seperti Hadits yang diriwayatkan oleh Ahmad, Bukhari, Nasa'i dan lbnu Majah yang berbunyi:

Artinya:"Rasulullah SAW pernah menggadaikan baju besi kepada seorang Yahudi di Madinah, sebagai jaminan ketika beliau mengutang gandum dari seorang Yahudi". ${ }^{2}$

Dari hadits tersebut di atas, praktek muamalah lintas agama juga pernah dilakukan oleh Rasulullah SAW pada waktu itu, yakni beliau menggadaikan baju besinya kepada seorang Yahudi sebagai jaminan ketika beliau mengutang gandum kepada mereka (kaum Yahudi). Hal

\footnotetext{
${ }^{1}$ Ali Mutasowifin, Menggagas Strategi Pengembangan Perbankan Syamil di Pasar Non Muslim, Jurnal Elektronik Universitas Paramadina Vol 3 No 1, September 2003, h.25. Dalam http://www.scibd.com. (diakses Rabu, 06 April 2011)

${ }^{2}$ Hendi Suhendi, Fiqh Muamalah, Jakarta: PT. Raja Grafindo Persada. 2002, h.107
} 
ini dilakukan oleh Rasulullah SAW sebagai bentuk refleksi dari hakikat beliau sebagai makhluk sosial atau makhluk Allah Swt yang masih membutuhkan orang lain di dalam kehidupannya. Hal tersebut juga dilakukan oleh Rasulullah SAW sebagai bentuk refleksi dari perintah Allah Swt yang mengutus beliau ke dunia ini sebagai rahmat bagi sekalian alam (rahmatan lil 'alamin) yang tercantum dalam Q.S Al-Anbiya:107 yang berbunyi:

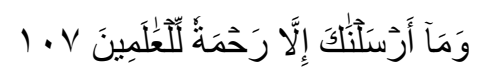

Artinya: Dan tiadalah Kami mengutus kamu (Muhammad), melainkan untuk (menjadi) rahmat bagi semesta alam. ${ }^{3}$

Dari ayat tersebut menyatakan bahwa Allah Swt telah mengutus Nabi Muhammad SAW sebagai rahmat bagi sekalian alam (rahmatan lil alamin), yang mencakup tidak hanya untuk orang mukmin, melainkan untuk semua umat manusia dan semua makhluk di alam jagad raya ini. Dengan demikian, maka hal inilah yang Lembaga Keuangan Syariah (LKS), khususnya bank syariah coba untuk menerapkannya dalam setiap transaksi dan operasaional perbankan yang mereka lakukan.

Seiring dengan semakin pesatnya perkembangan perbankan syariah di Indonesia, maka Bank Syariah Mandiri (BSM) juga telah mengambil bagian untuk menjadi salah satu bank umum yang berhijrah menuju bank yang menerapkan konsep syariah, atau dapat disebut juga bank yang menggunakan sistem perbankan ganda (Dual Banking System).

Bank Syariah Mandiri (BSM) dengan visinya menjadi bank syariah terpercaya pilihan mitra usaha, senantiasa menjalin kemitraan dengan semua kalangan, tanpa membedakan latar belakang suku, agama dan warna kulit dalam bingkai semangat Islam sebagai "rahmatan lil'alamiin ".

Dengan semakin berkembang pesatnya Bank Syariah Mandiri di Indonesia, akhirnya telah sampai juga di Bumi Tambun Bungai provinsi Kalimantan Tengah khususnya di ibu kota Palangka Raya, dengan operasionalnya yang menggunakan konsep syariah untuk mendampingi Lembaga Keuangan Syariah (LKS) yang ada di Palangka Raya, seperti Bank Muamalat (BMI) cabang Palangka Raya, Baitul maal wat Tamwil (BMT), Pegadaian Syariah, Asuransi Syariah, dan juga yang kini baru hadir yakni BNI Syariah cabang Palangka Raya.

Hadirya Bank Syariah Mandiri di kota Palangka Raya pada pertengahan. tahun 2010 sebagai Bank yang mendampingi BMI cabang Palangka Raya dan Lembaga Keuangan lainnya yang menggunakan prinsip syariah, membuat industri pemasaran Lembaga Keuangan Syariah (LKS) di Provinsi Kalimantan Tengah, khususnya di kota Palangka Raya ini semakin dilirik oleh masyarakat yang notabene jumlah penduduknya hampir seimbang antara muslim dan nonmuslim yakni sekitar $67 \%$ beragama muslim dan $33 \%$ beragama non-muslim. ${ }^{4}$

\footnotetext{
${ }^{3}$ Departemen Agama RI. Al Qur'an dan Terjemahnya, Diponegoro Cv. Penerbit Dipinegoro, 2005, h. 461

${ }^{4}$ Departemen Agama SIAK, Kota Palangka Raya Dalam angka Tahun 2010, Palangka Raya: Dinas Kependudukan dan Catatan Sipil Kota Palangka Raya. Dalam http://www.slideshare.net (Diakses Selasa, 13 Desenber 2011).
} 
Berdasarkan observasi penulis, terhitung sejak diresmikan dan dibukanya Bank Syariah Mandiri cabang Palangka Raya sejak tahun 2010 hingga sekarang, maka persentasi yang menjadi nasabah terbanyak adalah nasabah yang beragama non-muslim dengan jumlah $70 \%{ }^{5}$ Dengan demikian, yang menjadi pertanyaannya adalah, mengapa lebih banyak masyarakat non-muslim yang cenderung memilih bertransaksi di Bank Syariah Mandiri cabang Palangka Raya dibandingkan dengan masyarakat yang muslim. Hal inilah yang menjadi latar belakang dan daya tarik bagi penulis untuk melakukan studi ini.

\section{B. [hasil dan Pembahasan] \\ 1. Perilaku Manusia}

Perilaku manusia (human behavior) merupakan objek kajian yang sangat kompleks dan rumit. Perilaku tidak hanya terkait dengan pertimbangan yang bersifat fisik (material), tetapi melibatkan faktor yang bersifat mentalitas-subjektif". ${ }^{6}$

Unsur-unsur subjektif yang menjadi rujukan dasar bagi seseorang dalam memutuskan suatu keputusan untuk bertindak dan berperilaku, sudah barang tentu sangat bervariasi. Hal ini terkait erat dengan selera dan cita rasa, keyakinan, pandangan hidup dan termasuk gaya hidup seseorang antara satu dengan lainnya berbeda. Implikasikan bahwa meskipun individu antara satu dengan lainnya memiliki pandangan objektif yang sama antara satu dan lainnya terhadap suatu simbol (materi), namun .secara subjektif belum tentu mencerminkan hal yang sama". ${ }^{7}$

Hal ini menyiratkan bahwa ada unsur nilai, keyakinan dan aspek-aspek lain yang menjadi dasar rujukan seorang individu dalam menetapkan suatu pilihan untuk bertindak atau tidak bertindak. Dengan instrumen akal, hati dan pengetahuan, pemahaman serta budayanya yang membedakannya dengan ciptaan Allah yang lain, manusia memiliki otonomi dalam menentukan preferensi, sikap dan perilakunya. la juga mampu berkomunikasi dengan dirinya sendiri serta dengan organisme lain yang ada di luar dirinya serta lingkungan hidupnya. ${ }^{8}$

Menurut Soerjono, keberadaan manusia tidak lepas dari kemampuan diri (self ability) untuk berinteraksi (to interact) dengan diri, lingkungan internal dan lingkungan eksternalnya. Dua faktur ini memiliki pengaruh besar dalam mengonstruk sikap, tindakan dan perilaku seseorang. ${ }^{9}$

Menurut Mead, Blummer, pada hakikatnya seseorang melakukan tindakan, atas dasar makna-makna yang dapat ditafsirkan dari simboi-simbol sosial yang ia hadapi. Sementara simbol-simbol itu sendiri tidak memiliki makna bagi dirinya sendiri, kecuali telah melalui proses interaksi sosial yang kompleks dan melibatkan banyak individu. Kemudian berdasarkan pada makna-makna tersebut dan menilai situasi disekelilingnya baru orang tersebut melakukan suatu

\footnotetext{
${ }^{5}$ Hasil interview dengan salah satu karyawan Bank Syariah Mandiri (BSM) cabang Palangka Raya berinisial SDN yang juga menjadi dosen pengampu mata kuliah "Manajemen Pemasaran Bank Syariah" pada hari Sabtu, 12 Maret 2011 pukul 14.25 WIB, diruang Kuliah E2.2 jurusan Syariah STAIN Palangka Raya

${ }^{6}$ Muhammad, Geliat-geliat Pemikiran Ekonomi Islam, Malang: Aditiya Media Publishing. 2010, h. 19

${ }^{7}$ Ibid., h. 20

${ }^{8}$ Ibid.

${ }^{9}$ Ibid.
} 
tindakan. Tindakan ini akan menjadi simbol bagi, dan akan dikonsumsi oleh orang lain melalui proses yang sama seperti ia menafsirkan semula. ${ }^{10}$

Pandangan di atas mengisyaratkan bahwa perilaku dan tindakan seseorang bergantung pada orang lain melalui proses interaksi sosial, sehingga ia dapat memahami suatu makna tertentu yang kemudian menilai serta mengkonsumsinya.

\section{Perilaku Konsumen}

Perilaku konsumen (consumer behavior) adalah suatu perilaku seseorang dengan pendapatan yang diperolehnya dapat membeli berbagai barang dan jasa sehingga tercapai kepuasan tertentu sesuai dengan apa yang diharapkannya. ${ }^{11}$

Menurut Engel, et. al yang dikutip oleh Muhammad bahwa perilaku konsumen dapat dipahami sebagai tindakan-tindakan individu (act of individuals) yang secara langsung terlibat dalam usaha memperoleh dan menggunakan barang-barang jasa ekonomis termasuk proses pengambilan keputusan (the decision process) yang mengawali dan menentukan tindakan tersebut. ${ }^{12}$

Perilaku konsumen adalah tindakan yang langsung terlibat dalam mendapatkan, mengkonsumsi dan menghabiskan peroduk atau jasa, termasuk proses keputusan yang mendahului dan menyusuli tindakan ini. ${ }^{13}$

The American Marketing Association, mendefinisikan perilaku konsumen merupakan interaksi dinamis antara afeksi dan kognisi, perilaku dan lingkungannya dimana manusia melakukan kegiatan pertukaran dalam hidup mereka". ${ }^{14}$

Menurut Leon Schiffman, bahwa perilaku konsumen terpusat pada cara individu mengambil keputusan untuk memanfaatkan sumber daya mereka yang tersedia (waktu, uang, usaha) guna membeli barang-barang yang berhubungan dengan konsumsi. ${ }^{15}$

Menurut Mannan, bahwa perilaku konsumsi dalam ekonomi konvensional dipahami sebagai upaya yang dilakukan seseorang untuk memenuhi kebutuhannya sehingga tercapai kepuasan secara Optimal. Penekanannya adalah pada kepuasan lahiriah. Hal ini berbeda dengan penekanan tujuan dan fungsi perilaku konsumsi dalam ekonom Islam, yakni memenuhi kebutuhan baik jasmani maupun rohani; sehingga mampu memaksimalkan fungsi kemanusiaannya sebagai hamba Allah untuk mendapatkan kebahagiaan dunia dan akhirat $($ falah $) .{ }^{16}$

\section{Preferensi}

\footnotetext{
${ }^{10}$ Muhammad, Geliat-geliat Pemikiran Ekonomi Islam,...h.24.

${ }^{11}$ Dicky Syuhada, Teori Perilaku Konsumen. Dalam http://dickysyuhada.blogspot.com. (diakses Minggu, 29 April 2012)

12 Muhammad, Geliat-geliat Pemikiran Ekonomi Islam,...h.31.

${ }^{13}$ Nugroho J. Setiadi, Perilaku Konsumen (Konsep dan Implikasi Untuk Strategi dan Penelitian Pemasaran), Bogor: Kencana, 2003, h.3.

${ }^{14}$ Ibid.

${ }^{15}$ Ikrima Nailul Sari, Faktor-faktor Yang Mempengaruhi Nasabah Memilih Bank Muamalat Cabang Batam Tahun 2009-2010”, Skripsi, Yogyakarta: Universitas Islam Indonesia, 2010.h. 11-12. Dalam http://rac.uii.ac.id (Diakses Sabtu 26 November 2011)

${ }^{16}$ Muhammad, Geliat-geliat Pemikiran Ekonomi Islam,...h.32.
} 
Preferensi berasal bahasa Inggris preference. Dalam Kamus Besar Bahasa Indonesia, preferensi diartikan sebagai suatu hal yang harus didahulukan, dan diutamakan dari pada yang lain, prioritas, pilihan, kecenderungan dan yang lebih disukai. ${ }^{17}$

Preferensi dapat juga diartikan sebagai kecenderungan terhadap sesuatu hal atau pilihan yang lebih disenangi. Preferensi atau selera adalah sebuah konsep, yang digunakan pada ilmu sosial, khususnya ekonomi. Ini mengasumsikan pilihan realitas atau imajiner antara alternatifalternatif dan kemungkinan dari pemeringkatan alternatif tersebut, berdasarkan kesenangan, kepuasan, gratifikasi, pemenuhan, kegunaan yang ada. Lebih luas lagi, bisa dilihat sebagai sumber dari motivasi. Di ilmu kognitif, preferensi indiwdual memungkinkan pemilihan tujuan/goal. ${ }^{18}$

\section{a. Preferensi Nasabah}

Preferensi nasabah menabung atau berinvestasi pada suatu bank adalah keinginan atau kecenderungan mereka untuk memilih transaksi seharusnya melakukan keuangan. Preferensi nasabah dalam memilih suatu bank sangat bervariasi, karena setiap individu mempunfyai keinginan atau kebutuhan serta kepentingan berbeda-beda dalam memilih bank.

Preferensi nasabah dapat diperoleh berdasarkan faktor-faktor yang menjadi dasar pertimbangan pemilihan suatu bank, baik di perbankan konvensional maupun di perbankan syariah. Dasar pertimbangan tersebut misalnya, seperti informasi dan promosi yang diperoleh melalui iklan atau spanduk, keberadaan lokasi, kebutuhan, keuntungan, keamanan, produk, pelayanan, pengetahuan dan fasilitas. Selain itu juga. kalau diperbankan syariah, khususnya yang mendorong sebagian besar masyarakat muslim adalah keyakinan atas dasar agama yang bersumber dari al-Qur'an dan hadits yang melarang keras melakukan transaksi riba dan lain-lain.

\section{b. Faktor Yang Mempengaruhi}

Ada dua faktor yang mempengaruhi preferensi nasabah dalam memilih suatu bank, yakni faktor internal dan faktor eksternal, dengan rincian sebagai berikut:

\section{a. Faktor Intemal adalah:}

1) Faktor pribadi yang terdiri dari usia, pekerjaan, pendapatan, dan jenis kelamin.

2) Faktor psikologis yang terdiri dari motivasi, persepsi dan pembelajaran.

3) Faktor konsumen/nasabah yang terdiri dari kenyamanan, kesenangan, keamanan ketentraman, keuntungan, dan kebutuhan.

\section{b. Faktor eksternal adalah:}

1) Faktor budaya yang terdiri dari agama, kelompok suku dan bahasa.

2) Faktor sosial yang terdiri dari keluarga, teman, tetangga, peran dan status sosial.

3) Faktor lembaga perusahaan/Bank yang terdiri dari bukti fisik, informasi, promosi, iklan, spanduk, lokasi, pelayanan, fasilitas, produk, dan kenyamanan nasabah. ${ }^{19}$

\section{Bank Syariah}

\footnotetext{
${ }^{17}$ Dinas Pendidikan Nasional, Kamus Besar Bahasa Indonesia. Jakarta: Balai Pustaka, 2002.h.894

${ }^{18}$ Wikipedia bahasa Indonesia Ensiklopedia Bebas, Dalam http://id.wikipedia.org. (Diakses Kamis, 26 November 2011)

${ }^{19}$ Ikrima Nailul Sari, Faktor-faktor Yang Mempengaruhi Nasabah...h. 15-20
} 
Bank syariah terbentuk dari dua kata yaitu bank dan syariah bermakna suatu lembaga keuangan yang berfungsi sebagai perantara keuangan dari dua pihak, yaitu pihak yang berlebihan (surflus) dan pihak yang kekurangan dana (defisit). Sementara kata syariah dalam versi bank syariah di lndonesia adalah aturan perjanjian berdasarkan yang dilakukan oleh pihak bank dan pihak lain untuk penyimpana dana atau pembiayaan kegiatan usaha dan kegiatan lainnya sesuai dengan hukum Islam.

Penggabungan kedua kata dimaksud, menjadi "bank syariah". Bank syariah adalah suatu lembaga keuangan yang berfungsi sebagai perantara bagi pihak yang berlebihan dana (surflus) dengan pihak yang kekurangan dana (defisit) untuk kegiatan usaha dan kegiatan lainnya sesuai dengan hukum Islam. Selain itu, bank syariah dapat disebut Islamic Banking atau interest fee banking, yaitu suatu sesuatu sistem perbankan dalam pelaksanaan operasional tidak menggunakan sistem bunga (riba), Spekulasi (maysir) dan ketidakpastian atau ketidakjelasan (gaharar). ${ }^{20}$

Bank Islam (baca:syariah) seara struktural fungsional tidak bebeda dari tujuan dan fungsi pokok bank-bank konvensional. Namun, secara fungsi yuridis antara bank syariah dengan bank konvensional memiliki perbedaan yang mendasar yakni; bank Islam adalah bank yang melakukan operasionalnya berlandaskan aturan-aturan hukum Islam yang sumber utamanya adalah al-Qur'an dan Hadis, yang sangat melarang sekaligus mengharamkan transaksi riba. ${ }^{21} \mathrm{Hal}$ ini dapat kita lihat dalam Q.S Ali Imran: 130 yang berbunyi:

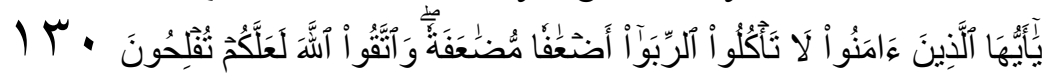

Artinya: "Hai orang-orang yang beriman! janganlah kamu memakan riba dengan berlipat ganda dan bertakwalah kamu kepada Allah supaya kamu mendapat keberuntungan". ${ }^{22}$

Banyak para ilmuwan memberikan definisi tentang perbankan syariah sesuai dengan sudut pandang mereka masing-masing yakni diantaranya adalah:

Sudarsono, berpendapat bahwa: yang dimaksud dengan bank syariah aalah lembaga keuangan yang usaha pokoknya memberikan kredit dan jasa-jasa lain dalam lalu lintas pembayarannya serta peredaran uang yang beroperasi dengan prinsip-prinsip syariah. ${ }^{23}$

Menurut Muhammad sebagaimana yang dikutip oleh Donna, bank syariah adalah lembaga keuangan yang beroperasi dengan tidak mengandalkan pada bunga yang usaha pokoknya memberikan pembiayaan dan jasa-jasa lainnya dalam lalu lintas pembayaran serta pengedaran uang yang pengoperasian nya sesuai dengan pnnsup-prinsnp syariat Islam. ${ }^{24}$

\section{Hasil Studi Lapangan}

\footnotetext{
${ }^{20}$ Zainuddin Ali, Hukum Perbankan Syariah, Jakarta: Sinar Grafika, 2008,h.1

21 Muhammad, "Kekuatan Ekonomi Islam Dalam Menciptakan Kesejahteraan Masyarakat”, makalah disajikan dalam seminar Nasional Ekonomi Islam diselenggarakan LPM Equator Kalimantan Tengah, Februari 2011, h.1, di Palangka Raya

${ }^{22}$ Departemen Agama RI, Al-Qur'an dan Terjemahnya,..., h.66

${ }^{23}$ Buchari alma dan donni Juni Priansa, Manjaemen Bisnis Syariah. Bandung: Alfabeta, 2009, h.6-7

${ }^{24}$ Ibid..h.7
} 
Dalam studi ini penulis melakukan penggalian data di lapangan, menggunakan teknik wawancara dan kuisioner terhadap nasabah non-mushm pada Bank Syariah Mandiri cabang Palangka Raya yang menjadi subjek sebanyak 6 orang nasabah. Secata umum mereka memiliki keberagaman pendapat tergantung dari jenis produk bank yang mereka pilih baik produk pembiayaan ataupun produk tabungan sesuai dengan kebutuhan indivndu mereka masingmasing.

Kelompok subjek sebanyak 3 orang yang menjadi nasabah pembiayaan di Bank Syariah Mandiri cabang Palangka Raya, secara umumnya memiliki kesamaan pendapat dalam melakukan pembiayaan di bank tersebut yakni karena margin pembiayaannya yang kecut dan karena angsuran pembayaran pembiayaannya tetap hingga sampai jatuh tempo pelunasan.

Hal ini, diperkuat dengan adanya pernyataan oleh salah satu marketing Bank Syariah Mandiri cabang Palangka Raya saat diwawancarai oleh penulis, beliau mengatakan bahwa salah satu strategi pemasaran mereka dalam memasarkan produk BSM implan kepada para nasabah adalah meyakinkan para nasabah, bahwa untuk angsuran pembiayaan produk tersebut tidak akan mengalami perubahan kenaikan (tetap) hingga sampai patuh tempo pelunasan, sehingga para nasabah tersebut mendapatkan kepastian dalam pembiayaan. ${ }^{25}$

Selanjutnya, dari ketiga subyek tersebut menambahkan hal lam yang menyebabkan mereka cenderung memilih Bank Syariah Mandiri cabang Palangka Raya yakni karena pelayanan karyawannya yang baik. persyaratan pembiayaannya yang mudah. dan karena pelayanan karyawannya yang baik dan ramah.

Kemudian kelompok subjek yang lain sebanyak 3 orang yang menjadi nasabah penabung di Bank Syariah Mandiri cabang Palangka Raya, juga memiliki kesamaan pendapat dalam menabung atau menyimpan uang mereka di bank tersebut, yakni karena antrian nasabahnya yang sedikit dan tidak banyak seperti bank lain. Selanjutnya. dari ketiga subjek tersebut ada 2 subjek yang menambahkan hal lain sebagai faktor penyebab mereka berdua cenderung memilih menabung di Bank Syariah Mandiri cabang Palangka Raya yakni karena pelayanan karyawannya yang nyaman, baik dan cepat proses pelayanannya.

Hasil temuan penulis di lapangan juga menunjukkan bahwa apa yang menjadi preferensi keenam subjek nasabah non-muslim tersebut di atas, tidak jauh berbeda dengan preferensi nasabah yang beragama muslim. Dari 2 orang nasabah muslim yang menjadi informan penulis menemukan bahwa kedua informan teraebut cenderung memilih Bank Syariah Mandiri cabang Palangka Raya sebagai tempat bertransaksi menabung ataupun melakukan transaksi pembiayaan dikarenakan adanya keramahan karyawan dalam melakukan pelayanan dan juga dikarenakan sedikitnya antrian nasabah dalam Bank tersebut.

Dengan demikian, dapat disimpulkan bahwa preferensi nasabah muslim dan nasabah nonmuslim terhadap Bank Syariah Mandiri cabang Palangka Raya tidaklah jauh berbeda, yakni bukan atas dasar motivasi dan pertimbangan agama, akan tetapi atas dasar pelayanan karyawan bank itu sendiri yang ramah, kelengkapan fasilitas yang disediakan banknya, antrian yang tidak banyak seperti bank lain, dan keuntungan yang didapatkan nasabah, baik keuntungan bagi hasil maupun keuntungan margin pembiayaan yang relatif lebih kecil atau murah.

${ }^{25}$ Sumber: hasil wawancara dengan salah satu karyawan bagian marketing pembiayaan Bank Syariah Mandiri Cabang Palangka Raya yang berinisial TJN pada hari Kamis, 13 Juli 2012 
Mengenai tanggapan nasabah non-muslim terhadap produk Bank Syariah Mandiri cabang Palangka Raya, penulis menemukan bahwa mayoritas ke 6 subjek tersebut memberikan tanggapan terhadap produk Bank Syariah Mandiri cabang Palangka Raya adalah biasa-biasa saja, dengan asumsi bahwa produk Bank Syariah Mandiri hampir sama dengan produk bank-bank lain, walaupun awalnya memang kesulitan untuk memahami maksud produk tersebut, namun setelah mendapatkan penjelasan dari karyawan banknya, mereka pun akhirnya paham terhadap maksud dari produk tersebut. Selanjutnya, menurut para subjek tersebut selain ada kesamaaan antara produk Bank Syariah Mandiri dengan produk bank-bank lain, juga ada sedikit yang membedakannya yaitu adanya bagi hasil yang didapatkan dari uang tabungan nasabah walaupun relatif kecil, murahnya angsuran pembiayaan, serta adanya ketetapan atau kepastian dalam pembayaran angsuran pembiayaannya yang tidak akan berubah sampai jatuh tempo pelunasan.

Berkaitan dengan faktor yang mendorong nasabah non-rnuslim cenderung memilih bertransaksi di Bank Syariah Mandiri cabang Palangka Raya, dari ke 6 subjek yang telah diteliti, penulis menemukan bahwa faktor yang mendorong mereka mendorong memilih bertransaksi di Bank Syariah Mandiri cabang Palangka Raya secara umumnya memiliki kesamaan yakni karena faktor pelayanan karyawan bank itu sendiri yang baik menurut mereka. Selanjutnya, dari ke 6 subjek tersebut juga mempunyai faktor lain yang mendorong mereka cenderung memilih bertransaksi di Bank Syariah Mandiri cabang Palangka Raya yang disesuaikan dengan kebutuhan masing-masing subjek tersebut terhadap produk Bank Syariah Mandiri yang mereka pilih yakni produk tabungan dan produk pembiayaan.

Tiga orang subjek yang merupakan nasabah penabung di Bank Syariah Mandiri mempunyai kesamaan pendapat bahwa selain faktor di atas, faktor lain yang mendorong mereka cenderung memilih bertransaksi menabung di Bank Syariah Mandiri cabang Palangka Raya adalah karena antrian nasabah yang tidak banyak seperti bank-bank lain dan pelayanan karyawannya yang baik. Kemudian faktor lain, selain dari faktor tersebut adalah karena adanya kelengkapan fasilitas yang disediakan banknya, baik fasilitas kantor, maupun fasilitas pelayanannya, serta karena bank tersebut Sudah menggunakan fasilitas sistem online, yang membuat nasabah tidak sulit untuk mengambil atau menarik uang tabungan mereka. Selain itu, dalam hal proses pengiriman uang ke luar daerah, menurut salah satu subyek yang pernah mengirim uang untuk keluarganya yang berada di daerah pulau Jawa, di Bank Syariah Mandiri proses pengirimannya cepat dengan biaya pengiriman yang relatif murah.

Selanjutnya, 3 orang subjek yang merupakan nasabah pembiayaan juga mempunyai faktor lain selain yang diungkapkan mereka di atas. Adapun faktor lain tersebut adalah karena margin pembiayaannya kecil dan pembayaran angsurannya yang tidak mengalami kenaikan (tetap) hingga sampai jatuh tempo pelunasan dan karena persyaratan pembiayaannya mudah, serta fasilitas banknya yang lengkap seperti halnya bank-bank lain menurut mereka.

Dari hasil temuan di lapangan, penulis juga menemukan ada dua faktor yang mendorong nasabah non-muslim cenderung memilih Bank Syariah Mandiri cabang Palangka Raya yakni atas dasar faktor internal yang terdiri dari faktor kebutuhan dari konsumen atau nasabah itu sendiri dan faktor eksternal yang terdiri dari factor lembaga perusahaan atau banknya.

Berdasarkan kedua faktor tersebut, dari seluruh subjek dalam riset ini, mayoritas mengaku bahwa mereka cenderung bertransaksi di Bank Syariah Mandiri cabang Palangka Raya karena faktor eksternalnya yaitu faktor lembaga perusahaan atau banknya yang terdiri dari pelayanan, 
fasilitas dan kenyamanan nasabah. Dari masing-masing faktor tersebut, semua subjek mengaku faktor dominan adalah pelayanan dan kenyamanan nasabah yakni dikarenakan antrian yang tidak banyak dan pelayanan karyawannya yang baik dan nyaman. Selain Itu, mereka juga mengakui faktor fasilitas, yakni karena kelengkapan fasilitas yang disediakan pihak bank seperti Mesin ATM, sistem online, mobile banking, dan internet banking.

Dari keenam subyek tersebut, tiga di antaranya mengakui yang dominan karena faktor internal yaitu atas dasar kebutuhan konsumen atau nasabah yang terdiri dari keuntungan dan kebutuhan. Mereka berada pada faktor internal atas dasar alasan karena margin pembiayaannya kecil, pembayaran angsurannya tetap dan karena kebutuhan pribadi atau keluarga mereka terpenuhi.

Dari hasil penggalian di lapangan, juga telah ditemukan bahwa faktor yang membuat nasabah non muslim cenderung memilih bertransaksi pada Bank Syariah Mandiri cabang Palangka Raya, tidak jauh berbeda dengan nasabah yang muslim. Hal ini penulis temukan melalui wawancara kepada 2 orang informan yang mengatakan bahwa mereka cenderung memilih bertransaksi di Bank Syariah Mandiri cabang Palangka Raya adalah karena pelayanan karyawannya yang baik, lengkapnya fasilitas yang disediakan bank, antrian nasabah yang tidak banyak seperti bank lain, serta karena pelayanan karyawannya yang ramah.

Dengan demikian dapat disimpulkan bahwa faktor yang mendorong nasabah muslim dan nonmuslim cenderung memilih bertransaksi di Bank Syariah Mandiri cabang Palangka Raya tidak terdapat perbedaan yang signifikan, yakni bukan karena adanya motivasi dan pertimbangan agama (halal/haram), melainkan atas dasar faktor eksternal yaitu faktor lembaga perusahaan atau banknya yang terdlri dari pelayanan, fasilitas dan kenyamanan nasabah.

\section{Kesimpulan}

Hasil kajian di atas menunjukan bahwa preferensi nasabah non-muslim terhadap Bank Syariah Mandiri adalah karena pelayanan karyawan bank itu sendiri yang baik dan ramah, kelengkapan fasilitas yang disediakan banknya, antrian yang tidak banyak seperti bank lain, dan keuntungan yang didapatkan nasabah baik keuntungan bagi hasil maupun keuntungan margin pembiayaan yang relatif lebih kecil, serta keuntungan pembayaran angsuran pembiayaannya yang tidak mengalami kenaikan (tetap) hingga sampai jatuh tempo pelunasan.

Tanggapan nasabah non-muslim terhadap produk Bank Syariah Mandiri cabang Palangka Raya adalah biasa-biasa saja karena hampir sama dengan produk bank.lain, bagus, memudahkan dan menguntungkan karena adanya bagi hasil yang didapatkan dari tabungan walaupun relatif kecil, dan kecilnya margin pembiayaan yang diambil oleh bank tersebut dari uang pembiayaan kepada nasabah serta karena pembayaran angsuran pembiayaannya yang tetap.

Ada dua faktor yang mendorong nasabah non-muslim cenderung memilih bertransaksi di Bank Syariah Mandiri cabang Palangka Raya yaitu, faktor eksternal dan faktor intemal. Faktor eksternalnya yaitu faktor lembaga perusahaan atau bank yang terdiri dari pelayanan karyawannya yang baik dan ramah, kelengkapan fasilitas yang disediakan bank dan kenyamanan nasabah karena antrian yang tidak banyak seperti bank lain. Dan faktor internalnya yaitu faktor kebutuhan konsumen atau nasabah yang terdiri dari keuntungan yang didapatkan, baik keuntungan bagi hasil untuk nasabah penabung maupun keuntungan margin pembiayaan yang 
relatif kecil serta angsuran yang tetap untuk nasabah pembiayaan, serta karena adanya kebutuhan, baik kebutuhan pribadi maupun kebutuhan keluarga.

Faktor yang mendorong nasabah muslim dan non-muslim cenderung memilih bertransaksi di Bank Syariah Mandiri cabang Palangka Raya tidak terdapat perbedaan yang signifikan, yakni bukan karena adanya motivasi dan pertimbangan agama (Halal/Haram), melainkan atas dasar faktor eksternal yaitu faktor lembaga perusahaan atau banknya yang terdiri dari Pelayanan, fasilitas dan kenyamanan nasabah.

Hasil studi ini memperkuat pandangan yangmengatakan bahwa faktor agama (halal/hararn) bukanlah pertimbangan utama dalam pemilihan bank syariah. Namun, yang mendorong nasabah untuk memilih bertransaksi di bank syariah adalah karena faktor rasionalitas yang lahir dan tumbuh melekat dalam dirinya karena imbas dari sistem ekonomi konvensional yang sulit untuk dihilangkan, dimana ia selalu berpikir dan mempertimbangkan sesuatu itu menurutnya harus masuk akal, berkualitas, mudah dan nyata menguntungkan baginya. Selain itu juga, yang mendorong para nasabah cenderung bertransaksi di bank syariah adalah karena faktor dari lembaga perusahaan itu sendiri yang terdiri dari pelayanan, fasilitas dan kenyamanan nasabah untuk bertransaksi.

Pandangan tersebut tidak bermaksud mengenyampingkan pertimbangan agama (halal/haram), melainkan sebagai simbol bahwa ternyata para nasabah tersebut dalam mencapai kebebasan alamiahnya masih dipengaruhi oleh sifat rasionalitasnya yang dikendalikan oleh sistem ekonomi konvensional. Dengan demikian,ternyata sampai saat ini nilai-nilai agama masih belum bisa masuk ke sendi-sendi budaya ekonomi manusia, untuk mengendalikan dan membentengi mereka dari sistem dan budaya ekonomi yang cenderung lebih mengutamakan keuntungan duniawi daripada ukhrawi (wahn).

\section{DAFTAR PUSTAKA}

Ali, Zainuddin, Hukum Perbankan Syariah, Jakarta: Sinar Grafika, 2008.

Suhendi, Hendi, Fiqh Muamalah, Jakarta: PT. Raja Grafindo Persada, 2002.

Dinas Pendidikan Nasional, Ka'mus Besar Bahasa Indonesia, Jakarta: Balai Pustaka, 2002.

Muhammad, “Kekuatan Ekonomi Islam Dalam Mencfptakan Kesejahteraan

Masyarakat", Makalah seminar Nasional Ekonomi Islam oleh LPM Equator Kalimantan Tengah di Aula ]ayang Tingang, 2011.

,Geliat-Geliat Pemikiran Ekonomi Islam, Yogyakarta: Aditya Media Publishing. 2010. , Lembaga Ekonomi Syariah, Yogyakarta: Graha 1lmu, 2007. 
Setiadi, Nugroho J., Perilaku Konsumsi (Konsep dan Implikasi Untuk Strategi dan Penulisan Pemasaran, Bogor: Kencana, 2003.

Al Arif, Nur Rianto dan Ekis Amalia, Teori Mikro Ekonomi: Suatu Perbandingan Ekonomi Islam dan Ekonomi Konvensional, Jakarta: Kencana, 2010.

Nasution, Mustafa Edwin dkk, Pengenalan Ekslusif' Ekonomi Islam, Jakarta. Kencana, 2007

Muflih, Muhammad, Perilaku Konsumen Dalam Perspektif Ilmu Ekonomi Islam, Jakarta: Raja Grafindo Persada, 2006.

Alma, Buchari dan Doni Juni Priansa, Manajemen Bisnis Syariah, Bandung: Alfabeta, 2009.

Antonio, Muhammad Syafi'i, Bank Syariah: Dari Teori ke Parektik, Jakarta: Gema Insani Press, 2001.

Sudarsono, Heri, Bank dan Lembaga Keuangan Syariah (Deskripsi dan Ilustrasi), Yogyakarta: Ekonisia, 2007.

Departemen Agama RI, Al-Qur'an dan Terjemahnya, Diponegoro: Cv. Penerbit Diponegoro, 2005.

A. Karim, Adiwarman, Bank Islam: Analisis Fiqh dan Keuangan, Jakarta: Rajawali Pers, 2011.

Al Arif, M. Nur Rianto, Dasar-Dasar Pemasaran Bank Syariah, Bandung: Alfabeta, 2010.

Wirdyaningsih, dkk., Bank dan Asuransi Islam Di lndonesia, Jakarta: Kencana, 2003..

Daud, Abu, Shahih Sunan Abu Daud, terj. Muhammad Nashiruddin Al-Albani, Jakarta: Pustaka Azzam, 2006,

Amiruddin dan Zainal Asikin, Pengantar Metode Penulisan Hukum, Jakarta: Rajawali Pers, 2010 .

Arikunto, Suharsimi, Manajemen Penulisan, Jakarta: PT. Rhineka Cipta, 2003.

Mardalis, Metode Penulisan Suatu Pendekatan Proposal, Jakarta: PT Bumi Aksara, cet-IV, 2004.

Soeratno dan Lincolin Arsyad, Metodologi Penulisan (Untuk Ekonomi dan Bisnis), Yogyakarta: UPP AMP YKPN, 2003.

Meleong. Lexy, Metodologi Penulisan Kualitatif, Bandung: PT. Remaja Rosdakarya, 2004.

Sugiyono, Memahami Penulisan Kualitatif, Bandung: Alfabeta, 2004. .

Zuriah, Nurul, Metodologi Penulisan Sosial dan Pendidikan (Teori Aplikasi) Jakarta: PT. Bumi Aksara, 2006.

B. Milles, Matthew dan A. Michael Huberman, Analisis Data Kualitatif, terj. Tjetjep Rohendi Rohidi, Jakarta: Universitas Indonesia Press, 1999. 
Mandiri Syariah, BSM Basic Training, Jakarta: PT. Bank Syariah Mandiri, 2010.

Sudarman, Promosi Produk Unggulan Dari Bank Syariah Mandiri (BSM), makalah seminar regional ekonomi syariah, Palangka Raya: STAIN Palangka Raya, Sabtu, 30 Apri 12011.

Fitri,“ Analisis Faktor-Fakfor Yang Mempengaruhi Minal Masyarakat Terhadap Pembiayaan Perumahan Rakyat BMT Arhayibah, Proposal Skripsi, Palangka Raya: STAIN Palangka Raya, 2006 (t.d).

Hasan, Ali, Marketing Bank Syariah ( Cara jitu Meningkatkan Pertumbuhan Pasar Bank Syariah), Bogor: Ghalia Indonesia, 2010.

\section{Sumber Internet:}

Fatimah dan Dama, Potensi, Preferensi dan Perilaku Masyarakat Terhadap Bank Syariah di Kota Depok, Jurnal Ekonomi \& Bisnis, Vol. 5, No. 2, Depok: Ul Depok, Juli 2006, dalam http://isdj.pdii.lipi.go.id, diakses pada 6 April 2011.

Mutasowifin, Ali, Menggagas Strategi Pengembangan Perbankan Syariah di Pasar Non Muslim, Jurnal Elektronik Universitas Paramadina, Vol. 3 No. 1, September 2003, dalam: http://www.scribd.com, diakses pada 6 April 2011.

Majalah Infobank, Data Hasil Survey Majalah Infobank Bekerja Sama Dengan Mark Plus Insight, dalam http://www.infobanknews.com. diakses pada 4 Mei 2011.

Database SIAK, Dinas Kependudukan dan Catatan Sipil Kota Palangka Raya Per Desember 2010 (Kota Palangka Raya Dalam Angka Tahun 2010) dalam http://slideshare.net diakses pada 13 Desember 2011.

Lestari, Rani Widya, Preferensi dan Permintaan Masyarakat terhadap Produk-Produk Bank Syariah (Studi Kasus: Bank BTN Syariah dan Bank BNI Syariah di Yogyakarta), Thesis Mahasiswa UII Fakultas Ekonomi Yogyakarta, 2006 dalam , WW diakses' pada 26 November 2011 .

Munrokhim, Misanam \& Lili Liana, Bunga Bank, Bagi Hasil dan Relijiusitas: Suatu Investigasi Loyalitas Nasabah Terhadap Perbankan Syariah, Sinergi Kajian Bisnis dan Manajemen, Jurnal UII V01. 9. No. 1, januari, 2007, dalam http://www.google.co.id diakses pada 26 November 2011.

Harian Republika (24/02/2011), http://batavia.co.id, (diakses pada 12 Maret 2011).

Mutasowifin, Ali, Potensi, Preferensi dan Perilaku Masyarakat Terhadap Bank Syariah di Pulau lawn”, Menggagas Strategi Pengembangan Perbankan Syariah di Pasar Non-Mush'm, Jurnal, Universitas Paramadina Vol. 3 No. 1, September 2003: 25-39 dalam http://www.scribd.com, (diakses pada 6 April 2011).

Palupi, Mukhls'ma Dian, "Pengaruh Sistem Syariah dan Penjaminan Simpanan Terhadap Keputusan Nilai Simpanan Produk Deposito Mudharabah: Studi Kasus BPRS XYZ, 
(Thesis Penulisan Program Pascasarjana) Jakarta: Universitas Indonesia, 2008, dalam http://www.psktii-ui.com (diakses pada 26 November 2011).

Subiakto, Tesis: Preferensi Pengguna dan Penyedia Jasa Terhadap Sistem Jaringan Transportasi Jalan (IT)) yang Mendukung Pelabuhan di Kabupaten Belitung, Semarang: Universitas Diponegoro, 2009, dalam http://www.eprints.undip.ac.id diakses pada 26 November 2011.

Wikipedia Bahasa Indonesia Ensiklopedia Bebas dalam http://id.wikipedia.org diakses pada 26 November 2011).

Sari. 1krima Nailul, "Faktor-Faktor yang Mempengaruhi Nasabah Memilih Bank Muamalat Cabang Batam Tahun 2009-2010", Skripsi. Yogyakarta; U11, 2010 dalam http://www.rac.uii.ac.id diakses pada 26 November 2011

http://dickysyuhada.blogspot.com/2011/03/teori-perilaku-konsumen.html, diakses pada 29 April 2012. 